\title{
The Impact Of Audit Quality On Earnings Management To Achieve User Reference Points In EPS
}

Charles E. Jordan, University of Southern Mississippi, USA

Stanley J. Clark, University of Southern Mississippi, USA

Charlotte C. Hames, University of Southern Mississippi, USA

\begin{abstract}
Prior research (Thomas, 1989; Das and Zhang, 2003; Jordan et al., 2008a) presents evidence that managers manipulate income to round up earnings per share (EPS) to key user reference points when unrounded EPS fall only slightly below these breakpoints. In the U.S., studies on audit quality suggest that, relative to small audit firms, large CPA firms provide higher quality audits and, as such, more aggressively constrain their clients' attempts to manage earnings in general (e.g., see Francis and Krishnan, 1999; Krishnan, 2003). However, research outside the U.S. finds no consistent audit quality differential based on auditor size (e.g., see Piot and Janin, 2007; Maijoor and Vanstraelen, 2006). The current study examines whether audit quality, as proxied by auditor size, in the U.S. constrains earnings management to effect user reference points in EPS. Using the Big 4 versus non-Big 4 dichotomy as the measure of auditor size and audit quality, results suggest that audit quality significantly restricts management's attempts at rounding up EPS as clients of Big 4 firms show no major signs of this manipulative behavior while non-Big 4 auditees appear to round up the first digital position right of the decimal point in EPS across zero to increase the digit immediately left of the decimal point by one.
\end{abstract}

Keywords: earnings per share, earnings management, audit quality, audit firm size

\section{INTRODUCTION}

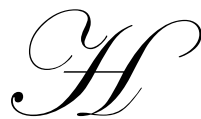

ealy and Wahlen (1999, p. 368) note that earnings management results from discretion in financial reporting with the intent of either misleading stakeholders about an entity's performance or influencing contractual outcomes that are based on accounting numbers. Earnings management can occur because accrual basis income depends on the use of estimates made in the financial reporting process. For example, current earnings could be boosted by underestimating bad debts on credit sales or expected warranty costs on the goods sold (Huang et al., 2008). In addition to using estimates to manipulate earnings, accounting method choices impact income with some procedures providing earnings-friendly effects (e.g., using FIFO inventory valuation rather than LIFO in the face of rising prices).

Income is often managed so that EPS figures reach desired levels. For example, the literature shows that earnings are manipulated to insure that EPS meets analysts' forecasts (e.g., see Payne and Robb, 2000; Jordan and Clark, 2003). This is done because share price is affected by investors' expectations concerning an entity's future cash flow (i.e., dividend paying) prospects. Since current EPS represents a signal of future cash flows, failing to meet analysts' forecasts of EPS often results in a depressed share price while meeting these forecasts brings about a maintenance or growth in stock price.

Earnings are also managed to reach user reference points in EPS. Here, the object of manipulation is not to meet analysts' expectations of EPS but rather to achieve cognitive reference points such as zeros or fives in the two digital positions right of the decimal point (e.g., see Das and Zhang, 2003). This type of earnings management 
occurs when unmanipulated EPS falls only slightly below the user reference points. Discretionary accruals are used to increase income until EPS can be rounded up to these desired breakpoints. Although this type of manipulation is often referred to as cosmetic earnings management (CEM), its results are anything but benign as Thomas (1989, $\mathrm{p}$. 774) notes that even "small changes in reported earnings [EPS] near user reference points have disproportionately large effects on perceived firm value."

The primary purpose of a financial statement audit is to provide users assurance that the statements are prepared in conformity with generally accepted accounting principles (GAAP). A key concept within GAAP is that financial reporting should provide information that is representationally faithful (i.e., financial statements should correctly portray the information they purport to represent). Earnings manipulation to achieve cognitive reference points in EPS seems to be in direct violation of the notion of representational faithfulness as the financial results are prepared not to reflect actual performance but rather to achieve predetermined outcomes. It stands to reason, then, that audit quality should be inversely related to the incidence of this form of earnings management.

Significant research in the U.S. suggests that large audit firms provide higher quality audits than small firms (e.g., see DeAngelo, 1981; Francis and Krishnan, 1999; Geiger and Rama, 2006; Khurana and Raman, 2004). This is due in part to the superior training of personnel and greater industry expertise that presumably exist with large CPA firms along with a stronger desire to protect their reputations and avoid costly litigation from failed audits relative to small audit firms. A specific stream of audit quality research in the U.S. further shows that, relative to small audit firms, large firms more aggressively constrain their clients' discretionary accruals and, thus, their ability to manage earnings in general (e.g., see Becker et al., 1998; Francis et al., 1999).

To date, however, no specific research exists on the impact of audit quality (as represented by auditor size) on earnings manipulation to achieve user reference points in EPS. The current study addresses this void in the literature by examining the incidence of this form of earnings management for a large sample of U.S. companies, first in whole and then segregated into two subsamples based on audit quality (i.e., auditor size measured as Big 4 versus non-Big 4). For the entire sample, clear signs of CEM appear in the EPS figures as unusually low frequencies of high numbers (i.e., eights and nines) and abnormally high rates of small numbers (i.e., zeros, ones, and twos) occur in the first digital position right of the decimal point in EPS. This represents a classic pattern of earnings manipulation to round up this digital position so that the digit immediately left of the decimal point increases by one. For the subsample of companies with non-Big 4 auditors, this same pattern of CEM in EPS emerges. For the clients of Big 4 auditors, though, no significant signs of CEM appear in EPS, thus supporting earlier research findings that audit quality (i.e., auditor size) acts as a restraint on earnings management.

\section{LITERATURE REVIEW}

Most of the literature on CEM deals with rounding earnings to reach cognitive reference points in income. Carslaw (1988) notes that humans attach the most emphasis to the first (i.e., left-most) digit within a number and increasingly less importance on the second, third, etc. digits. In the number 3,927, three appears as the first digit with nine as the second digit and so on. Brenner and Brenner (1982) indicate that humans possess only a limited amount of memory and, therefore, store only the most relevant information about a number in their minds. Thus, investors would tend to remember primarily the most important digits within a number. For example, Carslaw (1988) suggests that investors would remember $\$ 398$ million in earnings by rounding it down to $\$ 390$ million or perhaps even to $\$ 300$ million. Therefore, to prevent investors from rounding earnings down when unmanipulated income falls only slightly below user reference points, management will find ways to manipulate earnings to round it up to just across the breakpoint. In the example above, management would round earnings up from \$398 million to something slightly above $\$ 400$ million.

Significant research across many time periods and countries shows that this form of CEM occurs with great regularity (e.g., see Carslaw, 1988; Thomas, 1989; Niskanen and Keloharju, 2000; Van Caneghem, 2002; Kinnunen and Koskela, 2003; Skousen et al., 2004; Jordan et al., 2008b). All these studies examine the second earnings digit and indicate that this digital position contains abnormally lower rates of high numbers (e.g., eights and nines) and higher frequencies of small numbers (e.g., zeros and ones) than would be anticipated in unmanipulated earnings. All other numbers appear in the second earnings position at rates approximating their expected frequencies. From this 
result, each researcher concludes similarly that when the second earnings digit falls just below zero, management rounds income up so that the second digit just reaches or crosses over zero. The object of this manipulation is to increase the most important digit (i.e., the first digit) by one.

The studies referred to in the previous paragraph examine earnings management to achieve cognitive reference points in income, which is different than earnings management to reach user reference points in EPS. That is, a company could not round up earnings to reach a user reference point in income while also doing so to reach a user reference point in EPS. The two types of earnings manipulation are mutually exclusive for a given entity. Only three studies examine earnings manipulation to achieve user reference points in EPS. In the first of these, Thomas (1989) analyzes distributions of numbers in the right-most EPS digit (i.e., the digit two places right of the decimal point) for a large sample of U.S. companies. He finds that for entities with positive earnings zeros and fives appear in this digital position far more often than expected. The median deviation for zeros is as high as 36 percent of the expected frequency and nearly 16 percent for fives. No unusual patterns occur in the digital frequencies for companies with negative income. From these results, Thomas (1989) surmises that the right-most digit is used as a reference point for EPS numbers. For an explanation of why zeros and fives appear in this position at unusually high rates, he proffers the $\$ 1.99$ pricing phenomenon as a possible reason. That is, consumers view a price of $\$ 2.00$ as substantially higher than a price of $\$ 1.99$. Extending this to financial reporting, investors would likely perceive an EPS of $\$ .20$ as much higher than $\$ .19$. Thus, when unmanipulated EPS falls only slightly below a user reference point (i.e., a zero or five in the right digit), management finds ways to round earnings up until the user reference point in EPS is achieved.

Das and Zhang (2003) extend Thomas's (1989) work by examining the digital frequencies appearing in the position immediately right of the decimal point in the EPS numbers for a sample of U.S. companies. For entities with positive income, they find that the frequency of numbers appearing in this digital position steadily decreases from the number one to the number four but then abruptly increases at the point of five. This discontinuity at the point of five is statistically significant. For the numbers five through zero (i.e., five, six, seven, eight, nine, and zero) the frequencies remain relatively stable. Das and Zhang (2003, p. 40) conclude that their "evidence is consistent with managers manipulating earnings upward to round-up reported EPS." They further surmise that managers are more motivated to manipulate earnings to round up EPS when unmanipulated EPS numbers are close to behavioral benchmarks. Finally, Das and Zhang (2003) present evidence that managers accomplish the earnings manipulation needed to round up EPS via short-term accruals.

Jordan et al. (2008a) extend the work of Thomas (1989) and Das and Zhang (2003) by examining whether the propensity to engage in CEM with respect to EPS is related to specific company characteristics (i.e., entity size, operating performance, and debt leverage). Analyzing a sample of U.S. companies, like Thomas (1989) they test for unusual digital patterns in the right-most position of EPS. However, contrary to Thomas (1989) who finds abnormally high distributions of fives and zeros in this position for companies with positive earnings, Jordan et al. (2008a) discover no unusual digital patterns for their full sample of entities. When their sample is segregated by company characteristics, though, unusual digital patterns and signs of earnings manipulation emerge. The strongest signs occur when company size is examined but with the subgroups of large and small entities exhibiting different patterns of EPS manipulation.

The small entities possess significantly more zeros than expected in the right EPS position, which is consistent with the $\$ 1.99$ pricing phenomenon. The large companies, though, report significantly higher frequencies of sixes and lower rates of ones than expected in this position. Jordan et al. (2008a) note that the reasons for these unusual patterns for the large entities are unknown, but they are intuitive. The number one is the smallest non-zero number and management would likely prefer not to have this number in the right-most EPS position. This would be especially true if EPS is relatively low. "For example, an EPS of \$.02 is much larger and more desirable than an EPS of \$.01 (Jordan et al., 2008a, p. 37)." The researchers note that the higher than expected rate of sixes could be occurring simply because management seeks to get the right EPS digit into the upper half of the digital range.

All three of the above studies examining digital patterns in EPS provide evidence of CEM in relation to EPS. More specifically, the research suggests that earnings are managed so that EPS can be rounded up to desirable reference points. The next section of the literature review examines studies dealing with audit quality and its effect on earnings management in general. 
Craswell et al. (1995) note that Big N (i.e., 8/7/6/5/4) auditors may be able to provide higher quality audits than non-Big $\mathrm{N}$ auditors because the former group devotes more resources to staff training and developing industry expertise relative to non-Big N firms. Krishnan (2003) posits that because of their size Big N auditors are in a better position, relative to non-Big $\mathrm{N}$ auditors, to question or negotiate with clients who attempt to adopt aggressive accounting procedures. That is, relative to non-Big $\mathrm{N}$ auditors, Big $\mathrm{N}$ firms can more easily absorb the financial loss associated with losing an individual client, which gives them greater independence. Blokdijk et al. (2006) find that an audit quality differential exists for Big $\mathrm{N}$ auditors compared to non-Big $\mathrm{N}$ auditors not because of the time involved in an engagement but because of differences in audit technologies and how the audits are conducted.

There also exists a belief that Big $\mathrm{N}$ auditors provide higher quality audits than non-Big $\mathrm{N}$ firms because Big $\mathrm{N}$ auditors have larger client bases and, therefore, have more to lose in the event of loss of reputation that would be associated with a poorly performed audit (e.g., see Becker et al., 1998). Finally, a significant stream of research suggests that Big $\mathrm{N}$ auditors provide higher quality audits relative to non-Big $\mathrm{N}$ firms to minimize the litigation risks or costs accompanying a failed audit (e.g., see DeAngelo, 1981; Simunic and Stein, 1996; Khurana and Raman, 2004; Geiger and Rama, 2006). Because of the large audit firms' "deep pockets" and, thus, their huge exposure to litigation risks, these firms may take more conservative approaches to dealing with their clients' questionable transactions than would small audit firms.

Becker et al. (1998) suggest that the effectiveness of an audit in constraining earnings management varies directly with the quality of the audit. For the many reasons noted above, there is a presumption in the literature that, relative to non-Big $\mathrm{N}$ auditors, Big $\mathrm{N}$ auditors provide higher quality audits. As such, research examining the relationship between audit quality and earnings management typically uses auditor size and specifically the Big $\mathrm{N}$ versus non-Big $\mathrm{N}$ dichotomy as the surrogate measure for audit quality. For these studies conducted in the U.S., the evidence consistently supports the notion that, relative to non-Big $\mathrm{N}$ firms, Big $\mathrm{N}$ auditors more aggressively constrain their clients' discretionary accruals and, thus, their ability to manage earnings (e.g., see Becker et al., 1998; Francis et al., 1999; Francis and Krishnan, 1999; Krishnan, 2003).

Outside the U.S., though, studies generally provide little or no evidence of an audit quality (i.e., auditor size) differential in terms of constraining earnings management (e.g., see Vander Bauwhede and Willekens, 2004; Van Caneghem, 2004; Maijoor and Vanstraelen, 2006; Piot and Janin, 2007). Instead, the quality of an audit in nonU.S. countries seems to be a function of the national audit environment. Companies operating in countries with strict audit environments and strong investor protection schemes engage in less earnings management than entities in countries with flexible audit environments and weak investor protection schemes (e.g., see Maijoor and Vanstraelen, 2006; Francis and Wang, 2008). The U.S. has a stricter audit environment and more investor-friendly legal system than exist in most other nations, and this is likely the reason an audit quality differential based on auditor size occurs in the U.S. but not necessarily in other countries (Khurana and Raman, 2004; Piot and Janin, 2007). That is, in the U.S. Big $\mathrm{N}$ auditors provide higher quality audits relative to non-Big $\mathrm{N}$ firms to lessen their exposure to litigation risks.

The above studies present evidence that audit quality, as represented by auditor size, constrains earnings management in general in the U.S. but not necessarily outside the U.S. However, no prior research examines the effect of audit quality (i.e., auditor size) on the specific practice of managing earnings to reach desired reference points in EPS. For a sample of U.S. companies, the current study seeks to determine if audit quality constrains this particular form of earnings manipulation.

\section{METHODOLOGY}

As noted previously, research shows that auditor size proxies for audit quality with larger audit firms providing higher quality audits relative to smaller CPA firms (e.g., see DeAngelo, 1981; Khurana and Raman, 2004). The natural delineation for auditor size and the one used in prior studies on audit quality as a constraining factor on earnings management is the dichotomy of Big 4 versus non-Big 4 auditors. There is some question, however, concerning how to categorize mid-tier audit firms such as BDO Seidman, Grant Thornton, and McGladrey Pullen that possess characteristics of both Big 4 and non-Big 4 auditors. In examining going-concern reporting quality, Geiger and Rama (2006) discover a significant difference between Big 4 and non-Big 4 auditors but find no 
significant difference between mid-tier audit firms and lower-tier (i.e., regional/local) firms. For these reasons, the current study adopts the traditional Big 4 versus non-Big 4 classification as the measure of auditor size and, thus, the proxy for audit quality.

Prior research also shows that audit quality (i.e., auditor size) acts as a constraint on earnings management in general in the U.S. but not necessarily outside the U.S. (e.g., see Francis and Krishnan, 1999; Maijoor and Vanstraelen, 2006). Thus, to ascertain whether audit quality restricts earnings manipulation to achieve user reference points in EPS, the current research examines U.S. companies only. The sample companies are selected from those whose shares are traded on the NASDAQ, AMEX, and OTC exchanges. Entities listed on these exchanges provide a healthy mix of companies audited by Big 4 and non-Big 4 auditors. Because previous research (Thomas, 1989) demonstrates that CEM with respect to EPS is more likely to occur with entities generating positive income than with those reporting net losses, only companies with positive earnings are included in the sample. Select 2007 financial statement data are obtained from the Lexis Nexis Business database. The sample of companies contains all U.S. entities with positive 2007 income that are listed on one of the three exchanges noted above and are also included in the Lexis Nexis Business database. Using these selection parameters results in a total sample size of 1,251 companies with 631 and 620 of these audited by Big 4 and non-Big 4 audit firms, respectively.

Previous studies on earnings management to achieve user reference points in EPS concentrate on digital analysis of either the first or second digit right of the decimal point in basic EPS from continuing operations. The notion is that, generally, earnings manipulation can provide for the rounding up of EPS by only a few cents. Das and Zhang (2003) test for CEM in EPS by examining the first digit right of the decimal point, while Thomas (1989) and Jordan et al. (2008a) analyze the second digit right of the decimal point. The current study examines both the first and second digits right of the decimal point for signs of unusual patterns suggesting earnings rounding near user reference points.

Studies testing for CEM do so by comparing the actual frequencies of numbers (i.e., zero through nine) appearing in key digital positions with the expected frequencies of those numbers assuming no manipulative behavior. For example, Thomas (1989) shows that zeros and fives appear in the right-most EPS position far more often than anticipated, thus suggesting that earnings are manipulated so that the right EPS digit can be rounded up to these user reference points. A crucial issue for this study, then, is correctly identifying the appropriate expected frequency at which each number (i.e., zero through nine) should appear in the two digital positions right of the decimal point in EPS. Studies on CEM in relation to net income (e.g., see Van Caneghem, 2002; Skousen et al., 2004) use the expected frequencies as postulated by Benford (1938), who shows that for naturally occurring numbers the digits one through nine do not possess an equal likelihood of appearing in the first (i.e., left-most) digital position. Similarly, the numbers zero through nine do not occur in the second digital position in equal proportions. Instead, low numbers appear in these two digital positions more often than high numbers. For example, the first digital position within a naturally occurring number possesses a 30.10 percent chance of being a one and only a 4.60 percent likelihood of being a nine. For digital positions right of the second digit, though, each number (zero through nine) has an approximately equal chance of occurring.

However, Benford's expected frequencies do not apply to EPS numbers because EPS is a ratio rather than a naturally occurring number. In their studies examining digital patterns in EPS numbers, Das and Zhang (2003) and Jordan et al. (2008a) assume there is no a priori reason to believe the frequencies of numbers appearing in EPS positions right of the decimal point should be anything other than proportional. That is, each number from zero through nine possesses a 10 percent chance of appearing in these two digital positions. The current study uses these same expected proportions.

To test for unusual digital patterns in EPS, the actual frequency of each number (zero through nine) appearing in the positions right of the decimal point is compared to its expected frequency (i.e., 10 percent). Simple proportions tests and " $Z$ " values are used to ascertain the statistical significance of the differences between the observed and expected frequencies. Anomalies occurring in digital frequencies near user reference points (e.g., zeros or fives) suggest earnings manipulation consistent with CEM of EPS. The tests are first conducted on the full sample of 1,251 companies to ascertain whether earnings appear to be manipulated to achieve user reference points in EPS in general. Then, the full sample is segregated into two subsamples based on auditor size (i.e., Big 4 versus 
non-Big 4) and the tests for CEM in EPS are performed for each subsample to determine if audit quality, as proxied by auditor size, affects the propensity to manage earnings to effect user reference points in EPS.

\section{RESULTS}

No unusual digital patterns exist in the position two places right of the decimal point in EPS to suggest earnings manipulation to achieve user reference points. More specifically, the observed frequencies of numbers immediately adjacent to the user reference points of zero and five (and including zero and five) conform to their expected frequencies. For example, for the full sample, the observed frequencies of zeros and fives in the right-most EPS position are 9.11 percent and 8.95 percent, respectively. The expected frequency is, of course, 10 percent for each number. The p-levels for the differences between the observed and expected frequencies for zeros and fives in the right-most EPS position are .296 and .217 , respectively. Using a .01 alpha level leads to the conclusion that zeros and fives appear in this digital position at rates approximating their anticipated frequencies. If earnings are manipulated to achieve user reference points in the right-most EPS position, there should exists a significantly larger than expected occurrence of either zeros or fives (or both) in this position. However, this does not happen, which suggests there is no manipulation to achieve user reference points in the right-most EPS digit. The same findings hold true for the two subsamples separated by auditor size.

These results differ substantially from those of Thomas (1989) who finds evidence of earnings manipulation with significantly more zeros and fives than expected in the right-most EPS position. However, the results confirm the findings of Jordan et al. (2008a) where no unusual digital patterns occur in the right-most EPS position for their full sample of companies. This discrepancy in findings could be occurring because of the different time periods under study. Although all three studies examine U.S. companies, they do so in markedly different years. Thomas (1989) analyzes 1986 data, while Jordan et al. (2008a) examine 2006 data. Jordan et al. (2008a) posit that a possible explanation for the discrepancies in the findings is that the more recent data may have been affected by the heightened awareness and scrutiny of earnings management by the SEC and Congress following the egregious financial statement manipulations occurring in the recent past (e.g., Enron, WorldCom, Tyco, etc.). To avoid the stiff penalties now in place through the Sarbanes-Oxley Act, managers in 2006 may have been less prone to manipulate earnings relative to managers in 1986.

Whether this is the true reason for the difference between the findings of Thomas (1989) and Jordan et al. (2008a) is unknown. However, the results of the present research (which is based on 2007 data) provide additional support for the Jordan et al. (2008a) findings that, overall, management does not now appear to be manipulating earnings to achieve user points in the right-most EPS digit. This does not necessarily mean that earnings are not being managed to reach user reference points in EPS but only that the right-most position does not appear to be the object of any such manipulation.

Indeed, when examining the observed frequencies of numbers appearing in the digital position immediately right of the decimal point in EPS, strong signs of earnings manipulation emerge. For the full sample of 1,251 companies, Table 1 presents the observed counts and frequencies for each of the numbers zero through nine occurring in the digital position immediately right of the decimal point, hereafter referred to as the first decimal position (FDP). The table also shows the " $\mathrm{Z}$ " values and p-levels for a one-sample proportions test for the difference between the observed frequency of each number (zero through nine) appearing in the FDP and its expected frequency of 10 percent. Earnings manipulation to effect CEM in EPS would be suggested if unusual digital patterns occur in numbers adjacent to and including the user reference points of zero and five in the FDP.

Earnings management to achieve a user reference point of five in the FDP would be indicated by a significantly larger number of fives and an abnormally smaller number of threes and/or fours than expected in this position. However, using a .01 alpha level reveals no unusual digital patterns occur at or around the user reference point of five in the FDP. For example, Table 1 shows that the number five appears in the FDP 118 times, which is 9.4 percent of the total 1,251 observations. The "Z" value and p-level for the difference between this observed frequency and the expected frequency of 10 percent are -.67 and .50 , respectively. Similar results occur for the numbers three and four in the FDP (i.e., their observed frequencies conform to their expected frequencies). This suggests earnings are not manipulated to achieve a user reference point of five in the FDP of EPS. 
Table 1

Digital Frequencies for FDP in EPS for Full Sample

\begin{tabular}{llllllllllll}
\hline & \multicolumn{10}{c}{ Number appearing in FDP of EPS } \\
\hline & $\mathbf{0}$ & $\mathbf{1}$ & $\mathbf{2}$ & $\mathbf{3}$ & $\mathbf{4}$ & $\mathbf{5}$ & $\mathbf{6}$ & $\mathbf{7}$ & $\mathbf{8}$ & $\mathbf{9}$ \\
\hline & & & & & & & & & \\
Observed count (n) 185 & 158 & 157 & 134 & 115 & 118 & 106 & 103 & 81 & 94 & \\
Observed frequency (\%) & 14.8 & 12.6 & 12.5 & 10.7 & 9.2 & 9.4 & 8.5 & 8.2 & 6.5 & 7.5 \\
Expected frequency (\%) & 10.0 & 10.0 & 10.0 & 10.0 & 10.0 & 10.0 & 10.0 & 10.0 & 10.0 & 10.0 \\
Z value & 5.65 & 3.10 & 3.01 & 0.84 & -0.95 & -0.67 & -1.80 & -2.08 & -4.16 & -2.93 \\
p-level & .00 & .00 & .00 & .40 & .34 & .50 & .07 & .04 & .00 & .00 & \\
& & & & & & & & & & &
\end{tabular}

Note: $\mathrm{Z}$ values and p-levels are for a one-sample proportions test comparing the observed frequency of a number to the expected frequency of $10 \%$.

Instead, a pattern of earnings manipulation seems to occur with the object being the rounding of the FDP in EPS to or across zero. In particular, the two highest numbers (i.e., eight and nine) appear in the FDP much less often than anticipated with p-levels indicating that the differences between their observed and expected frequencies are statistically significant (i.e., p-levels of .00 for both eight and nine). Conversely, the three lowest numbers (i.e., zero, one, and two) occur in the FDP significantly more often than expected with p-levels for the differences between their observed and expected frequencies of .00 for each of them. The middle-range numbers, three through seven, appear in the FDP at rates approximating their expected frequencies (i.e., all of them possess p-levels exceeding the .01 alpha level).

The digital patterns for the FDP indicate a clear form of earnings manipulation to round up the FDP in EPS to increase the first position left of the decimal point by one. That is, when the FDP is high (i.e., an eight or nine), management apparently manipulates earnings to round up EPS until the FDP reaches or crosses zero, thereby increasing the first digit left of the decimal point by one. This represents a classic pattern of earnings rounding to increase the most important digit in a number (i.e., the left-most digit) by one. The vast majority of EPS numbers have only one digit left of the decimal point (i.e., very few companies possess EPS of $\$ 10$ or higher). Thus, rounding up the FDP to or across zero increases the most important digit (i.e., the dollar digit) by one.

Such earnings rounding to effect an increase in the left-most EPS digit by one has not been previously documented in CEM studies. Yet, this form of CEM is firmly founded in the $\$ 1.99$ pricing phenomenon posited by many (e.g., see Carslaw, 1988; Thomas, 1989) as a primary reason for earnings management to achieve cognitive reference points in earnings or EPS. As noted earlier, when rounding numbers, humans (i.e., investors) typically round down rather than up. Thus, when unmanipulated EPS falls just below a user reference point (e.g., \$1.96), rather than allowing investors to round this EPS figure down managers may instead manipulate earnings upward until EPS crosses the breakpoint (i.e., goes above \$2.00). The incentive for this earnings rounding is, of course, as Thomas (1989) notes that even small changes in earnings or EPS near user reference points can produce large effects on company value.

In addition to the digital patterns of the FDP in EPS shown in Table 1 suggesting classic signs of earnings rounding to achieve cognitive reference points in EPS, they also indicate aggressive manipulative behavior. With conservative manipulation to increase the first digit left of the decimal point by one, there should exist a lower frequency of nines and higher rate of zeros than expected in the FDP. That is, the rounding up would be over a relatively narrow range of the FDP. However, the rounding actually appears over a much wider range than merely from nines to zeros. Instead, rounding occurs in the FDP all the way from eights and nines to zeros, ones, and twos.

These results are similar to those of Niskanen and Keloharju (2000) who examine earnings rounding for a group of Finnish companies. In examining the second digital position in income, they find significantly lower frequencies of sixes and sevens and higher rates of zeros and ones than expected. This leads them to conclude that managers of Finnish entities practice aggressive manipulation by rounding up the second earnings digit over a wide range to increase the first digit by one. Previous studies on CEM at that time (i.e., Carslaw, 1988; Thomas, 1989) had shown that the rounding up of earnings was limited to cases where the second digit was very high (i.e., a nine) 
and then was rounded up just to the breakpoint (i.e., zero). Niskanen and Keloharju (2000) suggest that the earnings manipulation by Finnish managers to achieve user reference points in income is more than merely cosmetic. This same type of aggressive manipulative behavior appears to be occurring in the U.S. relative to achieving user reference points in the digital position in EPS immediately left of the decimal point.

When the full sample is separated according to audit quality (i.e., auditor size), interesting results appear in relation to rounding of the FDP in EPS. For the subsample of 620 companies audited by non-Big 4 firms, Table 2 provides the observed and expected frequencies for the numbers zero through nine occurring in the FDP. Also reported are the "Z" value and p-level for a proportions test for the difference between the observed and expected frequency for each of these numbers.

Table 2

Digital Frequencies for FDP in EPS for Non-Big 4 Clients

\begin{tabular}{llllllllllll}
\hline & \multicolumn{10}{c}{ Number appearing in FDP of EPS } \\
\hline & $\mathbf{0}$ & $\mathbf{1}$ & $\mathbf{2}$ & $\mathbf{3}$ & $\mathbf{4}$ & $\mathbf{5}$ & $\mathbf{6}$ & $\mathbf{7}$ & $\mathbf{8}$ & $\mathbf{9}$ \\
\hline & & & & & & & & & \\
Observed count (n) 109 & 85 & 81 & 62 & 55 & 47 & 51 & 53 & 35 & 42 & \\
Observed frequency (\%) & 17.6 & 13.7 & 13.1 & 10.0 & 8.9 & 7.6 & 8.2 & 8.6 & 5.7 & 6.8 \\
Expected frequency (\%) & 10.0 & 10.0 & 10.0 & 10.0 & 10.0 & 10.0 & 10.0 & 10.0 & 10.0 & 10.0 \\
Z value & 6.29 & 3.08 & 2.54 & 0 & -0.94 & -2.01 & -1.47 & -1.20 & -3.61 & -2.68 \\
p-level & .00 & .00 & .01 & 1.0 & .35 & .05 & .14 & .23 & .00 & .01 \\
& & & & & & & & & & \\
\hline
\end{tabular}

Note: $\mathrm{Z}$ values and p-levels are for a one-sample proportions test comparing the observed frequency of a number to the expected frequency of $10 \%$.

Notice that the results for the 620 companies audited by non-Big 4 firms echo those of the full sample in Table 1. Significantly fewer eights and nines and more zeros, ones, and twos than anticipated appear in the FDP of EPS (i.e., the p-level for each of these is .01 or lower). It seems non-Big 4 auditees engage in earnings management to round up the FDP in EPS across the breakpoint when the unmanipulated FDP falls within a couple of digits below that point. Such upward rounding of the FDP likely occurs to increase the digital position immediately left of the decimal point (i.e., the dollar digit) by one. Again, like the full sample, this manipulation appears aggressive as the range of rounding the FDP for the non-Big 4 auditess is more than merely from nines to zeros.

Table 3 presents the results for the $631 \mathrm{Big} 4$ auditees. The digital patterns for the FDP in EPS for these companies differ markedly from those of both the full sample and the subsample of Big 4 auditees presented in Tables 1 and 2, respectively. Some signs of earnings manipulation to effect CEM in EPS appear for the Big 4 auditees as Table 3 shows a lower than expected frequency occurs for each of the four highest numbers (i.e., six, seven, eight, and nine) in the FDP. Conversely, the four lowest numbers (i.e., zero, one, two, and three) appear in the FDP more often than anticipated. This digital pattern suggests than when the FDP in EPS is a high number, earnings are managed upward until the FDP crosses zero. This results in the first digit left of the decimal point increasing by one, which would be the real purpose of the manipulation.

Table 3

Digital Frequencies for FDP in EPS for Big 4 Clients

\begin{tabular}{llllllllllll}
\hline & \multicolumn{10}{c}{ Number appearing in FDP of EPS } \\
\hline & $\mathbf{0}$ & $\mathbf{1}$ & $\mathbf{2}$ & $\mathbf{3}$ & $\mathbf{4}$ & $\mathbf{5}$ & $\mathbf{6}$ & $\mathbf{7}$ & $\mathbf{8}$ & $\mathbf{9}$ \\
\hline & & & & & & & & & & \\
Observed count (n) 76 & 73 & 76 & 72 & 60 & 71 & 55 & 50 & 46 & 52 & \\
Observed frequency (\%) & 12.0 & 11.6 & 12.0 & 11.4 & 9.5 & 11.3 & 8.7 & 7.9 & 7.3 & 8.2 \\
Expected frequency (\%) & 10.0 & 10.0 & 10.0 & 10.0 & 10.0 & 10.0 & 10.0 & 10.0 & 10.0 & 10.0 \\
Z value & 1.71 & 1.31 & 1.71 & 1.18 & -0.41 & 1.05 & -1.07 & -1.74 & -2.27 & -1.47 \\
p-level & .09 & .19 & .09 & .24 & .68 & .29 & .28 & .08 & .02 & .14 &
\end{tabular}

Note: $\mathrm{Z}$ values and p-levels are for a one-sample proportions test comparing the observed frequency of a number to the expected frequency of $10 \%$. 
However, the proportions tests shown in Table 3 reveal that none of the observed and expected frequencies differ at a statistically significant level (i.e., each one possesses a p-level greater than the alpha level of .01). This suggests that any manipulation that might be occurring within the subsample of Big 4 auditees cannot be definitively proven as the anomalies noted in the digital patterns of the FDP in Table 3 may simply be due to random chance. Stated differently, it appears that Big 4 auditors constrain their clients' efforts to manipulate earnings to reach user reference points in EPS more aggressively than non-Big 4 auditors. Thus, using auditor size as a proxy for audit quality as suggested in prior research, these results indicate that audit quality restrains the practice of CEM in relation to EPS.

There is, of course, a possibility that the differences noted above in the propensity to engage in CEM relative to EPS may be impacted by factors other than audit quality (i.e., auditor size). Perhaps the clients of nonBig 4 auditors simply possess certain characteristics that make them more prone to earnings management than the clients of Big 4 auditors. For example, Jordan et al. (2008b) demonstrate that small companies practice CEM with respect to income more aggressively than large companies. Similarly, less profitable entities engage in this activity with greater intensity than more profitable ones (Jordan et al., 2008b).

If the clients of Big 4 versus non-Big 4 auditors differ only with respect to the size classification of their auditors, then clear evidence exists that it is the audit quality (i.e., auditor size) factor driving the results in Tables 2 and 3. However, if the subsamples of Big 4 and non-Big 4 auditees differ along traits other than auditor size, the relationship between audit quality, as proxied by auditor size, and the propensity to engage in CEM relative to EPS becomes a little more tenuous. Table 4 presents summary measures (i.e., medians) for the subsamples of Big 4 and non-Big 4 auditees along three financial traits (size as measured by total assets, profitability as represented by return on investment, and leverage as measured by the percentage of debt to total assets).

Table 4

Summary Measures of Financial Traits of Big 4 and Non-Big 4 Clients

\begin{tabular}{llcc}
\hline & $\begin{array}{l}\text { Median total } \\
\text { assets (000s) }\end{array}$ & $\begin{array}{l}\text { Median return } \\
\text { on investment }\end{array}$ & $\begin{array}{l}\text { Median debt } \\
\text { to total assets }\end{array}$ \\
Big 4 clients (n=631) & $\$ 708,588$ & $1.92 \%$ & $75.56 \%$ \\
Non-Big 4 clients $(\mathbf{n = 6 2 0})$ & 264,618 & .00 & .00 \\
\hline
\end{tabular}

Note: p-level is for a one-sample median test comparing amounts for the Big 4 clients to the median for the non-Big 4 clients.

On each of the financial traits measured, the group of non-Big 4 clients differs significantly from the group of Big 4 auditees. For example, the median total assets of the Big 4 auditees is almost $\$ 709$ million compared to only about $\$ 265$ million for the non-Big 4 clients. Relative to the Big 4 auditees, non-Big 4 clients are significantly smaller, less profitable, and more heavily burdened with debt. It is possible that these traits make the non-Big 4 auditees more prone to earnings management than the clients of Big 4 auditors. As an example, intuitively, less profitable companies would seem to have more need to manage EPS upward to key reference points than would more profitable entities. Similarly, heavily debt ladened companies may be perceived as riskier investments than ones with lower debt levels; thus, the former group may be more inclined to round up EPS to key reference points to make their stock more attractive to investors than would entities less burdened with debt.

The information in Table 4 suggests that companies possessing the financial traits associated with more need to manage EPS hire non-Big 4 auditors while entities with less need to manipulate EPS engage Big 4 auditors. Thus, it is conceivable that audit quality (i.e., auditor size) produces little or no affect on the propensity to manage earnings to reach user reference points in EPS but instead Big 4 auditors just happen to audit entities with little need or desire to manipulate EPS while non-Big 4 auditors have the unfortunate luck of auditing clients with a stronger need to manipulate EPS. A more likely scenario, though, is that companies desiring to manipulate income and EPS seek out auditors less likely to challenge their questionable accounting procedures. In essence, it is probably the audit quality (i.e., auditor size) factor that drives the auditor selection process and, as such, audit quality would seem 
to produce a major impact on the propensity to manipulate earnings to achieve desired reference points in EPS.

\section{SUMMARY AND CONCLUSION}

Prior studies (i.e., Thomas, 1989; Das and Zhang, 2003; Jordan et al., 2008a) present evidence that managers manipulate income in order to round up EPS to key user reference points, such as zeros or fives in the two digital positions right of the decimal point. Rounding EPS to these benchmark figures can produce significant effects on company value. Research on audit quality in the U.S. suggests that large audit firms provide higher quality audits than small firms and, as such, are better able to constrain their clients' attempts at earnings management in general than are small firms (e.g., see Francis et al., 1999; Krishnan, 2003). Outside the U.S., though, studies provide mixed results and often find no audit quality differential between large and small audit firms in terms of restricting earnings management (e.g., see Van Caneghem, 2004; Piot and Janin, 2007). It is speculated that an audit quality differential based on auditor size occurs in the U.S. but not consistently in other countries because of the greater litigation risks and more strict audit environment that exist in the U.S. relative to other countries. Because of their "deep pockets" and great exposure from litigation associated with a failed audit, large audit firms in the U.S. are more likely to take staunch stands against their clients' questionable accounting procedures than are small audit firms.

For a sample of U.S. companies, the current research attempts to ascertain whether audit quality, as proxied by auditor size, constrains one particular type of earnings management (i.e., earnings manipulation to achieve cognitive reference points in EPS). For the full sample of companies not delineated by audit quality (i.e., auditor size), a clear pattern of earnings manipulation with respect to EPS emerges as significantly fewer eights and nines and more zeros, ones, and twos than expected appear in the first digital position right of the decimal point. This suggests that when this digital position is a high number, earnings are managed upward to increase EPS until this digit reaches or crosses zero, thus resulting in the digit immediately left of the decimal point (i.e., the dollar position) increasing by one.

The full sample is then segregated into two subsamples using the dichotomy of Big 4 versus non-Big 4 auditor as the measure of auditor size and, thus, audit quality. For the subsample of non-Big 4 auditees, the same digital patterns appear in the first position right of the decimal point in EPS as occur for the full sample. This indicates that managers of companies audited by small audit firms manipulate earnings to round up EPS to user reference points. For the subsample of Big 4 auditees, though, no statistically significant differences occur between the observed and expected frequencies of the numbers one through nine appearing in the first digital position right of the decimal point, thus suggesting that the clients of large CPA firms do not manipulate earnings to achieve user reference points in EPS. Although it is possible the clients of Big 4 firms simply have less desire to manipulate EPS figures relative to the non-Big 4 auditees, a more probable explanation for the findings noted above is that large audit firms do a better job of constraining their clients' efforts at manipulating earnings and EPS than do small audit firms.

\section{SUGGESTIONS FOR FUTURE RESEARCH}

Previous research suggests that audit quality (i.e., auditor size) impacts the incidence of earnings management in general in the U.S. but not necessarily in other countries. For this reason, the current study examines only U.S. companies to ascertain whether audit quality constrains CEM in relation to EPS; results indicate that it does. Future research could replicate the present study in non-U.S. countries to determine if these findings are isolated to the U.S.

When examining the subsamples of Big 4 and non-Big 4 auditees, the present research discovers that these two groups possess markedly different financial traits. That is, relative to the Big 4 clients, the non-Big 4 auditees are on average significantly smaller, less profitable, and more heavily debt ladened. Future research could provide more definitive evidence on whether audit quality (i.e., auditor size) impacts the incidence of CEM relative to EPS by reducing the potential noise that exists in the current study from the different financial characteristics associated with the subsamples of Big 4 and non-Big 4 auditees. For example, the present study could be replicated using a sample of companies that do not differ significantly in terms of size. If similar results to those obtained in the 
current study occur, stronger evidence exists that audit quality, rather than client characteristics, impacts the likelihood that managers manipulate earnings to achieve user reference points in EPS.

\section{AUTHOR INFORMATION}

Charles E. Jordan, CPA, DBA, is a professor in the School of Accounting at the University of Southern Mississippi. His primary teaching and research areas are financial reporting. Dr. Jordan has on multiple occasions received the annual BellSouth Outstanding Faculty in the College of Business at the University of Southern Mississippi and was awarded the 2007-2008 Innovation in Applied Research Award for the university. He has published numerous articles in professional and academic journals, including Business Ethics Quarterly, Transportation Journal, Journal of Applied Business Research, Journal of Accountancy, and The CPA Journal.

Stanley J. Clark, CPA, Ph.D., is a Professor in the School of Accounting at the University of Southern Mississippi. His primary teaching areas are financial and tax accounting. His research has primarily focused on financial accounting and reporting issues. He is active professionally serving as discussion leader for numerous continuing education programs for local CPAs. He has published articles in several journals, including the Journal of Business and Economic Perspectives, Academy of Accounting and Financial Studies Journal, and Oil, Gas \& Energy Quarterly.

Charlotte C. Hames holds undergraduate degrees in both Accounting and Health Information Services. She has several years of administrative experience in private sector hospitals and, prior to this, served as an administrative assistant and court reporter in the U.S. Army for six years.

\section{REFERENCES}

1. Becker, C.L., M.L. DeFond, J. Jiambalvo, and K.R. Subramanyam, The Effect of Audit Quality on Earnings Management, Contemporary Accounting Research, Vol. 15, No. 1, pp. 1-24, 1998.

2. Benford, F., The Law of Anomalous Numbers, Proceedings of the American Philosophical Society, Vol. 78, No. 4, pp. 551-572, 1938.

3. Blokdijk, H., F. Drieenhuizen, D.A. Simunic, and M.T. Stein, An Analysis of Cross-sectional Differences in Big and Non-big Public Accounting Firms' Audit Programs, Auditing: A Journal of Practice \& Theory, Vol. 25, No. 1, pp. 27-48, 2006.

4. Brenner, G.A. and R. Brenner, Memory and Markets, or Why are You Paying \$2.99 for a Widget, The Journal of Business, Vol. 55, No. 1, pp. 147-158, 1982.

5. Carslaw, C.A.P.N., Anomalies in Income Numbers: Evidence of Goal Oriented Behavior, The Accounting Review, Vol. 63, No. 2, pp. 321-327, 1988.

6. Craswell, A., J. Francis and S. Taylor, Auditor Brand Name Reputations and Industry Specializations, Journal of Accounting and Economics, Vol. 20, No. 3, pp. 297-322, 1995.

7. Das, S. and H. Zhang, Rounding-up in Reported EPS, Behavioral Thresholds, and Earnings Management, Journal of Accounting and Economics, Vol. 35, No. 1, pp. 31-50, 2003.

8. DeAngelo, L.E., Auditor Size and Audit Quality, Journal of Accounting and Economics, Vol. 3, No. 2, pp. 183-199, 1981.

9. Francis, J. R. and J. Krishnan, Accounting Accruals and Auditor Reporting Conservatism, Contemporary Accounting Research, Vol. 16, No. 1, pp. 135-165, 1999.

10. Francis, J.R., E.L. Maydew, and H.C. Sparks, The Role of Big 6 Auditors in the Credible Reporting of Accruals, Auditing: A Journal of Practice \& Theory, Vol. 18, No. 2, pp. 17-34, 1999.

11. Francis, J.R. and D. Wang, The Joint Effect of Investor Protection and Big 4 Audits on Earnings Quality around the World, Contemporary Accounting Research, Vol. 25, No. 1, pp. 157-191, 2008.

12. Geiger, M.A. and D.V. Rama, Audit Firm Size and Going-Concern Reporting Accuracy, Accounting Horizons, Vol. 20, No. 1, pp. 1-17, 2006.

13. Healy, P.M. and J.M. Wahlen, A Review of the Earnings Management Literature and Its Implications for Standard Setting, Accounting Horizons, Vol. 13, No. 4, pp. 365-383, 1999.

14. Huang, P., T.J. Louwers, S.S. Moffitt, and Y. Zhang, Ethical Management, Corporate Governance, and Abnormal Accruals, Journal of Business Ethics, Vol. 83, No. 3, pp. 469-487, 2008. 
15. Jordan, C.E. and S.J. Clark, Evidence on the Level of Corporate America's Participation in the Earnings Game, The National Accounting Journal, Vol. 5, No. 1, pp. 61-70, 2003.

16. Jordan, C.E., S.J. Clark, and M. Anderson, Unusual Digital Patterns in EPS: Evidence on the Association between Earnings Management and Company Characteristics, Journal of Business \& Economics Research, Vol. 6, No. 1, pp. 31-40, 2008a.

17. Jordan, C.E., S.J. Clark, and G.R. Pate, Earnings Management to Achieve Cognitive Reference Points in Income, Academy of Accounting and Financial Studies Journal, Vol. 12, No. 3, pp. 97-112, $2008 \mathrm{~b}$.

18. Khurana, I.K. and K.K. Raman, Litigation Risk and the Financial Reporting Credibility of Big 4 versus Non-Big 4 Audits: Evidence from Anglo-American Countries, The Accounting Review, Vol. 79, No. 2, pp. 473-495, 2004.

19. Kinnunen, J. and M. Koskela, Who Is Miss World in Cosmetic Earnings Management? A Crosse-national Comparison of Small Upward Rounding of Net Income Numbers among Eighteen Countries, Journal of International Accounting Research, Vol. 2 pp. 39-68, 2003.

20. Krishnan, G.V., Audit Quality and the Pricing of Discretionary Accruals, Auditing: A Journal of Practice \& Theory, Vol. 22, No. 1, pp. 109-126, 2003.

21. Maijoor, S.J. and A. Vanstraelen, Earnings Management within Europe: The Effects of Member State Audit Environment, Audit Firm Quality, and International Capital Markets, Accounting and Business Research, Vol. 36, No. 1, pp. 33-52, 2006.

22. Niskanen, J. and M. Keloharju, Earnings Cosmetics in a Tax-driven Accounting Environment: Evidence from Finnish Public Firms, The European Accounting Review, Vol. 9, No. 3, pp. 443-452, 2000.

23. Payne, J.L. and S.W.G. Robb, Earnings Management: The Effect of Ex Ante Earnings Expectations, Journal of Accounting, Auditing and Finance, Vol. 15, No. 4, pp. 371-392, 2000.

24. Piot, C. and R. Janin, External Auditors, Audit Committees and Earnings Management in France, European Accounting Review, Vol. 16, No. 2, pp. 429-454, 2007.

25. Simunic, D. and M.T. Stein, The Impact of Litigation Risk on Audit Pricing: A Review of the Economics and Evidence, Auditing: A Journal of Practice \& Theory, Vol. 15, Supplement, pp. 119-134, 1996.

26. Skousen, C.J., L. Guan, and T.S. Wetzel, Anomalies and Unusual Patterns in Reported Earnings: Japanese Managers Round Earnings, Journal of International Financial Management \& Accounting, Vol. 15, No. 3, pp. 212-234, 2004.

27. Thomas, J.K., Unusual Patterns in Reported Earnings, The Accounting Review, Vol. 64, No. 4, pp. 773-787, 1989.

28. Van Caneghem, T., Earnings Management Induced by Cognitive Reference Points, British Accounting Review, Vol. 34, No. 2, pp. 167-178, 2002.

29. Van Caneghem, T., The Impact of Audit Quality on Earnings Rounding-up Behavior: Some U.K. Evidence, European Accounting Review, Vol. 13, No. 4, pp. 771-786, 2004.

30. Vander Bauwhede, H. and M. Willekens, Evidence on (the lack of) Audit Quality Differentiation in the Private Client Segment of the Belgian Audit Market, European Accounting Review, Vol. 13, No. 3, pp. 501-522, 2004. 